\title{
FUNÇÃO SOCIAL DA PROPRIEDADE E FUNÇÕES SOCIAIS DA CIDADE
}

SOCIAL FUNCTION OF THE PROPERTY AND SOCIAL FUNCTIONS OF THE CITY

\author{
Marcos Alcino de Azevedo Torres ${ }^{1}$ \\ Mauricio Jorge Pereira da Mota ${ }^{2}$
}

RESUMO: O presente trabalho busca identificar como as funções sociais da cidade densificam os interesses coletivos e individuais que se sujeitam a propriedade privada urbana no exercício de sua função social. Para tanto são investigados os fundamentos teóricos e filosóficos do direito de propriedade e de sua função social, bem como, problematizado o conteúdo e elementos das funções sociais da cidade.

PALAVRAS-CHAVES: Direito de propriedade; Função social; Funções sociais da cidade.

\footnotetext{
${ }^{1}$ Graduação em Direito pela Faculdade Brasileira de Ciências Jurídicas (1980), Mestrado em Direito pela Universidade do Estado do Rio de Janeiro (1997) e Doutorado em Direito pela Universidade do Estado do Rio de Janeiro (2004). Atualmente é Professor do Mestrado e Doutorado em Direito da Universidade do Estado do Rio de Janeiro, Professor Adjunto de Direito Civil da Universidade do Estado do Rio de Janeiro, Desembargador do Tribunal de Justiça do Estado do Rio de Janeiro, Presidente da 27ạ Câmara Cível especializada em Direito do Consumidor e Presidente da Comissão de Biblioteca do mesmo Tribunal. Presidente do Fórum Permanente de Direito da Cidade da Escola de Magistratura do Estado do Rio de Janeiro - EMERJ. Diretor de Estudos e Pesquisas da Associação dos Magistrados do Estado do Rio de Janeiro - AMAERJ. Diretor de Estudos Especiais do Instituto dos Magistrados Brasileiros - IMB. Tem experiência na área de Direito Civil, com ênfase em Direito de Propriedade, Posse, Direito da Cidade e Direito do Consumidor. E-mail: malcino@globo.com

${ }^{2}$ Graduação em Direito pela Pontifícia Universidade Católica do Rio de Janeiro (1994), mestrado em Direito pela Universidade do Estado do Rio de Janeiro (1997) e doutorado em Direito pela Universidade do Estado do Rio de Janeiro (2002). Atualmente é Professor do Mestrado e Doutorado em Direito da Universidade do Estado do Rio de Janeiro - UERJ, Professor do Doutorado em Meio Ambiente da Universidade do Estado do Rio de Janeiro - UERJ, Professor Adjunto da Universidade do Estado do Rio de Janeiro - UERJ e Procurador do Estado - Procuradoria Geral do Estado do Rio de Janeiro. Membro do Instituto dos Advogados Brasileiros - IAB. Editor Chefe da Revista Quaestio luris e da Revista de Direito da Cidade. Coordenador do Curso de Especialização em Advocacia Pública da Universidade do Estado do Rio de Janeiro - UERJ. Membro do Fórum Permanente de Direito da Cidade da Escola de Magistratura do Estado do Rio de Janeiro - EMERJ. Consultor da Coordenação de Aperfeiçoamento de Pessoal de Nível Superior (CAPES). Tem experiência na área de Direito, com ênfase em Direito Privado e Direito Ambiental, atuando principalmente nos seguintes temas: boa-fé, contratos, proteção ao devedor, políticas públicas, direito ambiental e controle da administração pública. E-mail: mjmota1@gmail.com
} 
ABSTRACT: The present work seeks to identify how the social functions of the city densify the collective and individual interests that are subject to urban private property in the exercise of its social function. For that, the theoretical and philosophical foundations of property rights and their social function are investigated, as well as the content and elements of the social functions of the city.

KEYWORDS: Property rights; Social role; Social functions of the city.

\section{INTRODUÇÃO}

É inegável, que o direito de propriedade tal qual os demais institutos jurídicos sofreram ao longo do tempo sucessivas transformações visando adequá-lo à realidade histórica e cultural de cada nação sofrendo influências de variadas idéias dominantes, que resultaram na sua conformação atual.

No presente trabalho busca-se apresentar desde a formação da propriedade até a crise da sua concepção liberal e individual, como o reconhecimento da função social integrante a própria noção do direito de propriedade implica na previsão de inúmeros deveres fundamentais ao seu titular pelo ordenamento jurídico.

Para a realização desse desiderato, examinar-se-ão os fundamentos teóricos e filosóficos do direito de propriedade, de modo a justificar a sua função social e permitir a sua interface no que tange a propriedade urbana às funções sociais da cidade prevista pela Constituição Federal.

\section{A APROPRIAÇÃO DOS BENS E A FORMAÇÃO DA NOÇÃO DE PROPRIEDADE}

É intuitivo que desde os primórdios da civilização o homem busca a satisfação de suas necessidades vitais ou não, nos bens existentes na natureza, algumas vezes satisfazendo necessidades físicas temporárias (p.ex. alimentação), outras vezes, necessidades físicas duradouras (p.ex. habitação).

Tais necessidades fazem parte de seu instinto de sobrevivência e atendimento delas se dá, num momento embrionário de existência. É através do apossamento de bens, seja tal ação interpretada como posse ou como propriedade, seja temporária ou duradoura esta situação de apossamento está presente na formação do homem. 
De uma forma ou de outra, o homem se apossa das coisas para consumi-las, para utilizálas ou para tê-las para $\mathrm{si}^{3}$, temporariamente ou em caráter duradouro até que dela se desinteresse e a abandone. Está situação natural e imaginável só passa a ter um especial interesse quando o homem atinge um certo nível de socialização que faz nascer um regramento de observância obrigatória que se desenvolve até a existência de um ente soberano encarregado de fazer observar compulsoriamente esse regramento. Nasce o Estado e após ele nascerá também a forma de apropriação das coisas que passou a ser conhecida como direito de propriedade.

Deste modo, somente após o homem construir um mínimo de organização social e jurídica é que se pode reconhecer a existência de um direito com a conotação do direito de propriedade, haja vista que fora desta consciência social e jurídica o respeito ao que é de cada um só se daria pela força ou pelo desinteresse em razão de um desvalor da coisa apossada. ${ }^{4}$

Neste contexto, pode-se supor que o instituto da posse, que não demanda organização jurídica para seu reconhecimento em razão do forte componente fático na sua formação, situação que sugere admissão natural por qualquer ser que tenha um mínimo de inteligência, teria existido, como forma de apossamento-apropriação das coisas primeiro do que o instituto da propriedade, com os contornos que esse instituto passou a ter.

Todavia, a fase pré-histórica do direito de propriedade é um ponto "obscuro da história do direito e sobre o qual não foi dita a última palavra" ${ }^{5}$. Assim, é costume ver-se nos autores, apesar de divergências quanto a ordem e o modelo, que a evolução dessa apropriação teria passado por sistemas diversos ${ }^{6}$.

\footnotetext{
${ }^{3}$ Interessante observar que a atitude de possuir, de achar-se possuidor ou proprietário, conforme o nome que o observador queira dar, independente de idade, sanidade ou qualquer outro elemento, como pode se observar nas crianças, ainda em tenra idade e naqueles que a cultura jurídica considera como incapazes. Daí é de ser ressaltada a redação da primeira parte do art. 443 do C.C. Espanhol: "los menores y los incapacitados pueden adquirir la posesión de las cosas; pero necesitan de la asistencia de sus representantes legítimos para usar de los derechos que de la posesión nascan a su favor."

${ }^{4}$ Neste tempo, ainda não se havia firmado a idéia de KANT do "meu jurídico ou meu direito (meum iuris)", ao qual está ligado o sujeito e "que o uso que um outro poderia " fazer dele sem o meu consentimento me prejudicaria". Apud BOBBIO, Norberto. Direito e Estado no Pensamento de E. Kant. 2a. ed. Edurb, 1992, p.95.

${ }^{5}$ MONTEIRO, Washington de Barros, Curso de Direito Civil. vol. 3. 37a ed. São Paulo: Saraiva, 2003. p. 80.

${ }^{6}$ Marnoco Souza sustenta a seguinte ordem: propriedade coletiva; propriedade individual e do predomínio de propriedade coletiva. SOUZA, Marnoco e. História das Instituições do Direito Romano, Penínsular e Portugues. Coimbra: Imprensa de Universidade, 1904, p. 319. Observa, contudo, Ralpho Monteiro Filho, que difícil é descrever com precisão qual foi a forma originária da propriedade, podendo ser dividida as opiniões sobre o assunto em duas correntes: "(i)a dos socialistas, preocupados em demonstrar a existência inicial de um comunismo geral das terras; e (ii) a dos economistas clássicos, decididos pela configuração primitiva da uma propriedade individual, de caráter absoluto e uniforme." MONTEIRO FILHO, Ralpho Waldo de Barro. Função social da propriedade: conteúdo e diretrizes para sua compreensão. Revista Forense. Vol. 397 p. 283.
} 
Segundo o sistema de propriedade coletiva, a primeira forma de propriedade foi a de apropriação comunista do solo por um grupo social, onde a terra cultivável, as pastagens e as florestas seriam exploradas em comum pela comunidade ${ }^{7}$, que predominava sobre o indivíduo. Foi a forma de propriedade que predominou nas antigas civilizações, como no Egito ${ }^{8}$. No Brasil é o modelo de propriedade que a nossa Constituição Federal reconheceu aos povos quilombolas no art. 68 do Ato das Disposições C. Transitórias.

De acordo com o sistema de propriedade individual, a propriedade na sua origem era semelhante a que conhecemos hoje, considerando os seus defensores como falsa a crença dos autores de que teria se originado de outra forma. Mesmo quando a propriedade pertence a família, ela era mais individual que comum, pois era atribuída a um membro da família, geralmente o pai. ${ }^{9}$

É perfeitamente possível imaginar que tanto a propriedade coletiva como a individual tenham existido na antiguidade, como ainda hoje, mas, é de se supor que o modelo de propriedade coletiva tenha sido mais difundido, até porque isso possibilitaria maior proteção do território ocupado, respeitando-se a propriedade individual relativa a coisas móveis de uso exclusivamente pessoal, como vestimentas, utensílios de caça e de defesa. Com desenvolvimento da humanidade, a propriedade individual vai ganhando novos contornos até atingir ao perfil que a conhecemos. ${ }^{10}$

Tal concepção, todavia, já foi objeto de críticas pela literatura ${ }^{11}$, já que as fases históricas sucessivas desse processo de apropriação (de comunidade de aldeia, comunidade de família e propriedade individual), não teria respaldo documental e buscaria rechaçar a idéia de propriedade coletiva ${ }^{12}$.

Por certo que na época em que havia abundância de solo e de alimentos, seria desnecessário reconhecer a propriedade privada de alguém, salvo dos bens de uso exclusivo (vestimentas, ferramentas, armas etc.). Era o homem de regra nômade e só quando descobriu a agricultura, atividade que necessariamente exigia sua permanência em determinado território é que se pode dizer que passou a ele a dar importância ao espaço ocupado, zelando e cuidando dele para o sucesso da empreitada agrícola.

\footnotetext{
7 Idem. Ibidem, p.319

${ }^{8}$ GASSEN, Valcir. A Natureza Histórica da Instituição do Direito de Propriedade. In Fundamentos de História do Direito, Org. Antonio Carlos Wolkmer, 2a ed. Belo Horizonte: Del Rey, 2006. p. 155-156.

${ }^{9}$ SOUZA, Marnoco e. História, op. cit. p.320

${ }^{10}$ Idem. Ibidem.

11 GONÇALVES, Luiz da Cunha. Tratado de Direito Civil em Comentário ao Código Civil Portugues. 2a edição. vol. XI. Tomo I, anotado por Jayme Landin. São Paulo: Max Limonad. 1968. p. 175.

12 Idem. p.176-177
} 
Basta lembrar que o Brasil na época do descobrimento era habitado apenas pelos Índios, que não tinham sequer noção de propriedade fosse individual ou coletiva da terra, quando muito se admitindo a propriedade de suas cabanas ou cubatas, desmontáveis, exercendo uma esfera de ação nos territórios destinados a caça, pertencente a cada uma das tribos, não se podendo, em rigor, considerar como propriedade coletiva. ${ }^{13}$

Ainda nesse contexto de formação da propriedade outros autores, preferem afirmar que os modelos propostos sempre existiram simultaneamente, de forma que um persiste sem excluir os outros ${ }^{14}$. Neste sentido, existiriam ao mesmo tempo todos os diversos modos de formação da propriedade e de sua proteção, não sendo a evolução tão ordenada e coerente dessa apropriação, como se tem na atualidade. ${ }^{15}$

De qualquer modo, é inegável que em dado momento, a sociedade política se organizou a ponto de regular essa apropriação humana sobre os bens, de forma a dar segurança e estabilidade pelas normas jurídicas à relação social formada pelo titular com a coletividade e aos membros do grupo em particular em relação ao objeto de sua apropriação.

Distintas teorias irão igualmente se preocupar com a justificação desse direito de apropriação sob os respectivos bens, uma vez que tal matéria, não é apenas uma questão jurídica, mas igualmente de interesse econômico, o que conduziu a amplo estudo e distintas controvérsias ${ }^{16}$.

Por sua vez a chamada teoria da ocupação fundamenta-se na primitiva ocupação da coisa pelo homem quando ainda se encontrava a mesma sem dono, isto é, era "res nullius". Não existindo domínio de ninguém sobre o bem, tornar-se-ia proprietário dele quem o ocupou e se apossou, submetendo-se ao seu poder. ${ }^{17}$

Apesar das críticas, em especial por sujeitar a aquisição a um ato de vontade do ocupante e desconsiderar que a aquisição só seria possível onde a lei permitisse, não parece absurdo crer que os bens naturais e abundantes, sem dono em um momento primitivo tiveram sua posse decorrente de um ato de ocupação gerando a propriedade. Na verdade, a aquisição da propriedade pela via da usucapião resultará sempre de um ato de ocupação continua e prolongada no tempo, situação que denota esse gesto de ocupar os bens com a intenção de deles

\footnotetext{
13 Idem. Ibidem, p.179

${ }^{14}$ GILISSEN, John. Introdução Histórica ao Direito.3 ed. Lisboa: Fundação Calouste, 1995. p. 636.

15 PASUKANIS, Eugeny B.. A Teoria Geral do Direito e o Marxismo. Rio de Janeiro: Renovar, 1989. p.86.

${ }^{16}$ GONÇALVES, Luiz da Cunha. Da propriedade..., op. cit., p. 20.

${ }^{17}$ RIZZARDO, Arnaldo. Direito das Coisas. 2a ed. Rio de Janeiro: Ed. Forense, 2006. p. 180.
} 
se tornar proprietário. Com a coisa móvel sem dono esse modelo é admitido pelo nosso código civil.

Para a teoria da convenção a propriedade sobre as coisas surgem primitivamente de uma convenção pela qual os homens se comprometeram a respeitar o direito que cada um deles adquirisse sobre as coisas, ocupando-as, a fim de poderem gozar tranquilamente os frutos de seu trabalho. ${ }^{18}$

Uma vez que o homem isolado é um mito ${ }^{19}$ e a vida em sociedade pressupõe o respeito a um mínimo de regras e onde há regras deve existir consequências para quem viola-las é perfeitamente possível imaginar este tipo de pacto implícito, entre membros de uma certa tribo, comunidade, povo, não importa a identificação que se dê para respeito acerca da apropriação das coisas.

Para a teoria do direito natural a apropriação dos bens deriva da própria natureza, tendo em vista ser ela uma condição necessária para o homem. Os bens naturais são de sua propriedade, para alguns, na medida que necessários para à sua sobrevivência e a realização da vida humana e para outros é apenas condição de seu bem estar. ${ }^{20}$

Assim nessa concepção, há os que afirmam que a propriedade é um direito natural, ou seja, um direito que nasce no estado de natureza, antes e independentemente do surgimento do Estado, e aquelas que negam e, portanto, sustentam que o direito de propriedade nasce somente como consequência da constituição do estado civil. ${ }^{21}$

Para a teoria do trabalho ou da especificação a origem da propriedade deriva do trabalho. O homem cultivando a terra e adotando as coisas externas à satisfação de suas necessidades, imprime aos objetos o cunho de sua personalidade, fazendo-os sair da comunidade primitiva, aberta aos esforços de todos. ${ }^{22}$

O direito de propriedade sobre os bens decorre do trabalho, sendo por meio deste que o homem usufrui da terra, cultiva-a, deixa-a fértil e frutífera. É justo, portanto que quem trabalha uma determinada porção de terra comum adquira o direito de usufruir dela com todos os benefícios relacionados, excluindo os outros, o que constitui a propriedade. ${ }^{23}$

\footnotetext{
18 souZA, Marnoco e. Op. cit., p. 314-315

19 “...o homem é um animal político, destinado a viver em sociedade” ARISTÓTELES. A Política. Trad. Nestor Silveira Chaves. 6ạ ed. São Paulo: Atena Editora, 1960, p. 14.

${ }^{20}$ BESSONE, Darcy. Direitos Reais. Rio de Janeiro: Saraiva, 1988, p. 24-25.

${ }^{21}$ COGLIOLO, Pietro. Op. cit. p. 170

22 BOBBIO, Noberto. Op. cit. p. 105

${ }^{23}$ BOBBIO, Noberto. Op. cit. p. 105.
} 
Para a teoria individualista ou da personalidade a propriedade sob os bens é tida a partir de uma concepção dinâmica, a qual exige uma constante integração entre o homem e a coisa possuída, de modo que continuamente se encha de uma atividade que a fecunde, que seja utilizada de modo permanente, através da ocupação e especificação (trabalho). ${ }^{24}$

Não é a propriedade o mesmo que um domínio do homem sobre os bens, mas uma certa relação entre o homem e os bens. Não são só os homens a tirar utilidade dos bens; os bens tem algo a exigir dos homens; exigem deles que as utilizem, que as gozem, as cultivem e as poupem, segundo o valor que elas têm. ${ }^{25}$

Para a teoria da criação da lei ou positivista a propriedade foi criada pelo Estado, não tendo a propriedade caráter jurídico sem a lei ou antes da lei, mas é atribuída pela norma do ente soberano. ${ }^{26}$ Para esta teoria a propriedade existe porque a lei quer e existirá enquanto a lei quiser, portanto seria a propriedade concessão do direito positivo.

De fato, o Estado enquanto situação de convivência humana em sua forma mais elevada ${ }^{27}$ corresponde à organização daquela sociedade em um território definido e que exerce sob ele a soberania ou o poder de fazer e executar leis, preservando a ordem social pela punição daqueles que infringem essas leis. ${ }^{28}$

Embora cada teoria apresente alguma forma de fundamento com proposito de indicar uma causa simples e única para uma instituição tão grande e variada como a propriedade, não deixa de ser uma percepção limitada, já que a propriedade enquanto um fato social é de todos os tempos e todos os povos civis. ${ }^{29}$

É possível reconhecer que estas teorias que procuram fundamentar ou justificar a propriedade privada embora sejam colocadas ou examinadas como excludentes entre sí, elas se entrelaçam e refletem uma evolução histórica no exame da questão até o reconhecimento da lei. ${ }^{30}$

\footnotetext{
${ }^{24}$ RADBRUCH, Gustav. Filosofia do Direito. Trad. L. Cabral de Moncada. 6a ed. Coimbra: Armênio Amado Editor, Sucessor, 1979, p. 272

${ }^{25}$ Idem, p. 273-274. Na verdade o autor faz um amplíssimo exame desta teoria, desenvolvendo o exame a partir da p. 272 até a p.278, quando passa a analisar as teorias sociais da propriedade.

${ }^{26}$ Idem. Principi di Diritto Naturale, p. 63, APUD Norberto Bobbio. Direito e Estado no Pensamento de Emanuel Kant. 2a edição. Editora Universidade de Brasília, 1992, p.103

${ }^{27}$ FISCHBACH, Oskar Georg. Teoria General del Estado. Trad. Rafael L. Tapia. 4a ed. Barcelona: Editorial Labor S-A., 1949, p.7.

${ }^{28}$ BURNS, Edward Mcnall. História da Civilização Ocidental. 1o vol. Trad. Alexandre Costa. Ed. Globo S-A, 1980, p.34

${ }^{29}$ COGLIOLO, Pietro. Op. cit. p.177.

30 PAPANO, Jose R., KIPER, Cláudio M., DILLON, Gregório A., CAUSSE, Jorge R. Derechos Reales. Tomo I. Buenos Aires: Ediciones Depalma, 1993, p.159
} 
Inegável, porém, que independente da teoria adotada, pode-se afirmar que há uma afirmação individualista da propriedade como uma apropriação de um sujeito sob o bem de forma a excluir os demais ainda que isto ocorra em razão da sua apropriação originária, do trabalho, do seu direito natural, por concessão da lei ou qualquer outra forma reconhecida pela sociedade em dado momento histórico e cultural de sua existência.

\section{DA CONCEPÇÃO LIBERAL À CRISE DA NOÇÃO INDIVIDUAL DE PROPRIEDADE}

Como visto, é um ato de apossamento do bem que vai resultar no fenômeno que a inteligência humana resolveu chamar de propriedade, de modo que a propriedade, seja ela tribal, familiar, individual ou pública é anterior à sua "juridicização ${ }^{31}$, ou melhor, a propriedade sempre existiu, mesmo antes da formulação de sua disciplina legal ${ }^{32}$.

Assim, embora seja indiscutível, que em algum momento houve a apropriação do bem que designamos como propriedade, não é possível identificar em que momento o homem construiu essa noção pelo menos conforme os conceitos modernos que se aplicam de direito subjetivo e direito de propriedade. ${ }^{33}$

Se não é possível delimitar com a certeza a época de seu nascimento ou sua conformação política, pode-se ao menos investigar o momento que o Estado Moderno passa a controlar e regular esse direito incidente sobre as coisas exteriores ao homem dando um caráter de segurança e estabilidade jurídica.

Costuma-se apontar como o primeiro documento liberal, que consagra as liberdades do cidadão em face do Estado e regula a propriedade como direito subjetivo, a Magna Charta

\footnotetext{
${ }^{31} \mathrm{KICH}$, Bruno C. A Propriedade na Ordem Jurídica, Econômica e Ideológica. Porto Alegre: Sérgio Fabris, 2004. p. 13.

32 RIZZARDO, Arnaldo. Op. cit. p. 180.

33 Idem, p.127-148.
} 
Libertatum que não apenas protege o direito de propriedade ${ }^{34}$, mas os limites à constrição do patrimônio com regras acerca das taxas ou tributos ${ }^{35}$.

Com as declarações de direitos da Virginia em 1776 e da França em 1789 a propriedade passa a ter a proteção do estado moderno, Estado de Direito para logo incorporarem-se as nascentes constituições, elaboradas pelo consenso dos cidadãos, cujos comandos deviam ser observados por estes, mas também pelo Estado e por seus agentes. ${ }^{36}$

Como fruto imediato das revoluções liberais burguesas, o reconhecimento da propriedade como direito subjetivo da pessoa acaba sendo na perspectiva liberal e individual com enfoque nas posições jurídicas atribuídas ao seu titular e nos deveres dos não proprietários em respeitá-las.

São tradicionais conceitos de propriedade como o direito que vincula e legalmente submete ao poder absoluto de nossa vontade a cousa corpórea, na substancia, acidentes e acessórios $^{37}$, que tem uma pessoa de tirar diretamente da $\operatorname{coisa}^{38}$ ou que vincula à nossa personalidade uma coisa corpórea sob todas as suas relações ${ }^{39}$.

\footnotetext{
34 "Considerando que foi para honra de Deus e bem do reino e para melhor aplanar o dissídio surgido entre nós e os nossos barões que outorgamos todas as coisas acabadas de referir; e querendo torná-las sólidas e duradouras, concedemos e aceitamos, para sua garantia, que os barões elejam livremente um conselho de vinte e cinco barões do reino, incumbidos de defender e observar e mandar observar a paz e as liberdades por nós reconhecidas e confirmadas pela presente Carta; e se nós, a nossa justiça, os nossos bailios ou algum dos nossos oficiais, em qualquer circunstância, deixarmos de respeitar essas liberdades em relação a qualquer pessoa ou violarmos alguma destas cláusulas de paz e segurança, e da ofensa for dada notícia a quatro barões escolhidos de entre os vinte e cinco para de tais fatos conhecerem, estes apelarão para nós ou, se estivermos ausentes do reino, para a nossa justiça, apontando as razões de queixa, e à petição será dada satisfação sem demora; e se por nós ou pela nossa justiça, no caso de estarmos fora do reino, a petição não for satisfeita dentro de quarenta dias, a contar do tempo em que foi exposta a ofensa, os mesmos quatro barões apresentarão o pleito aos restantes barões; e os vinte e cinco barões, juntamente com a comunidade de todo o reino (comuna totiu terrae), poderão embargar-nos e incomodarnos, apoderando-se de nossos castelos, terras e propriedades e utilizando quaisquer outros meios ao seu alcance, até ser atendida a sua pretensão, mas sem ofenderem a nossa pessoa e as pessoa da nossa rainha e dos nossos filhos, e, logo que tenha havido reparação, eles obedecer-nos-ão como antes. E qualquer pessoa neste reino poderá jurar obedecer às ordens dos vinte e cinco barões e juntar-se a eles para nos atacar; e nós damos pública e plena liberdade a quem quer que seja para assim agir, e não impediremos ninguém de fazer idêntico juramento." COMPARATO, Fábio Konder. A Afirmação Histórica dos Direitos Humanos. São Paulo, Ed. Saraiva, 1999. Op. Cit. p. 38.

35 "Não lançaremos taxas ou tributos sem o consentimento do conselho geral do reino (commue concilium regni), a não ser para resgate da nossa pessoa, para armar cavaleiro nosso filho mais velho e para celebrar, mas uma única vez, o casamento da nossa filha mais velha; e esses tributos não excederão limites razoáveis. De igual maneira se procederá quanto aos impostos da cidade de Londres". COMPARATO, Fábio Konder. Op. Cit. p. 68

${ }^{36} \mathrm{KICH}$, Bruno. A Declaração de Direitos influenciou na França a Constituição Gerondina de 1791 e a Constituição Jacobina de 1793 in a Propriedade na Ordem Jurídica... op. cit., p. 19.

${ }^{37}$ PEREIRA, Lafayette R. Direito das Coisas. Vol I. Brasilia: Senado Federal, 2004, p.98

${ }^{38}$ FULGÊNGIO, Tito. Direito de vizinhança. Rio de Janeiro: Forense, 1959, p. 7.

${ }^{39}$ ALMEIDA, Francisco de P. Lacerda de. Direito das cousas. Rio de janeiro: Ribeiro dos Santos, 1908, p. 72.
} 
Para alguns, inclusive, a regulamentação ocorre não apenas entre as relações dos homens em torno da coisa, mas da própria relação do sujeito com o seu bem, de forma que o direito de propriedade é tido como o direito subjetivo, que habilita o seu titular a dispor da coisa sem limitações, ou seja, permite proferir a última palavra acerca da coisa. ${ }^{40}$

Durante muito tempo sustentaram tal concepção do direito de propriedade sobre os bens em seu caráter absoluto ${ }^{41}$ embora desde a Antiguidade a propriedade já continha limites ${ }^{42}$, de modo que, o traço individualista os primeiros tempos vai sofrendo contínuas atenuações, cedendo lugar à penetração do elemento social. ${ }^{43}$

Tal crítica da definição tradicional de propriedade como domínio exclusivo de uma pessoa sobre uma coisa, já foi feita pela literatura jurídica, que apontava que tal concepção do direito de propriedade ignora a relação juridicamente essencial, isto é, à sua função econômico-social. ${ }^{44}$

Ainda sob a égide das teorias individualistas, a propriedade nunca foi rigorosamente individual, pois se assentava no pressuposto de uma harmonia preestabelecida entre o interesse individual e a utilidade gera ${ }^{45}$ algo comprovado pela incidência, por exemplo, ainda no Estado liberal clássico, do instituto do poder de polícia sobre as coisas.

Admitir o contrário seria anuir que a propriedade sobre os bens seria um direito fora e acima da sociedade apenas sujeito à satisfação de interesses individuais ${ }^{46}$ e de forma equivocada atribuir ao direito romano uma idéia de poder ilimitado ${ }^{47}$ já que eles tinham consciência dos perigos da concepção abstrata e absoluta do instituto da propriedade ${ }^{48}$.

Assim, neste período é necessário considerar que havia uma relativização do direito de propriedade, já que embora fosse uma relação de direito privado, não tornava sujeita

${ }^{40}$ RADBRUCH, Gustav. Filosofia do Direito. Trad. de L. Cabral Moncada. Coimbra: Armênio Ed., 1979, p. 267-268.

${ }^{41}$ Qualificação contestada por Clovis Bevilagua, que sustenta que todos os direitos são relativos. (D. das Coisas, ob. citada, p.263). A idéia de propriedade com característica de absoluta, decorreu, segundo Arruda Alvim, dos art. 554 e 555 do C. Civil Francês, por se interpretar que o proprietário podia inclusive "abusar" de seu direito de proprietário. BEVILAQUA, Posse... Op. cit. p.45.

${ }^{42}$ ALVES, José Carlos M.. Direito Romano. 9a edição. vol I. Rio de Janeiro: Forense, 1995, p. 285-289

${ }^{43}$ CRETELLA JUNIOR, José Curso de Direito Romano. 11a edição. Rio de Janeiro: Forense, 1987. p. 173

${ }^{44}$ KELSEN, Hans. Teoria Pura do Direito. Trad. João Batista Machado. São Paulo: Ed. Martins Fontes, 1985, p.144.

${ }^{45}$ RADBRUCH, Gustav. Filosofia do Direito. Tradução de L. Cabral Moncada..., op. cit., p.278 Ver no mesmo sentido ARRUDA ALVIM. Breves Anotações para uma Teoria Geral dos Direitos Reais, in Posse e Propriedade. São Paulo: Saraiva Ed., 1987, p. 45

${ }^{46}$ PEREIRA, Virgílio de Sá. Direito das Coisas. vol. VIII. São Paulo: Jacintho Ribeiro dos Santos, 1924, p.8

${ }^{47}$ PEZZELLA, Maria Cristina Cereser. Propriedade Privada no Direito Romano. Porto Alegre: Sergio A. Fabris Editor, 1998, p. 125.

48 IHERING, Rudolf von. A Finalidade do Direito. Tomo I. Trad. Heder K. Hoffmann, 1a ed. São Paulo: Bookseller Editora e Distribuidora, 2003. p. 348. 
completamente a vontade do seu titular, mas sujeito ao que não fosse vedado pelo direito público ou pela concorrência do direito alheio. ${ }^{49}$

Porém, tais concepções passam a ser superadas, pois o direito de propriedade, que passou a ter proteção constitucional gradativamente foi acompanhando com a evolução estatal acerca das suas discussões como um direito individual e a necessidade de sua adequação à função econômica e social, conforme a necessidade de maior intervenção estatal.

Esse movimento se inicia no final do século XIX com movimento doutrinário ${ }^{50}$ e coaduna com a gradual ascensão do Estado Social em suas distintas formas, que denotam mais do que uma crise dos paradigmas do Estado Liberal Clássico, em maior ou menor grau uma ingerência do ente estatal como forma de garantir certos fins como justiça social ${ }^{51}$.

Tal concepção incorpora-se à Constituição Mexicana de 1917 e à Constituição Weimar de 1919 e vai num crescendo durante todo século XX, inspirando outras constituições como a Constituição do Brasil de 1934, da Colômbia de 1945, da Itália de 1948, da Alemanha de 1949, de Portugal de 1976, da Espanha de 1978 até chegar ao século XXI.

Passa a propriedade privada nos países de inspiração romano-germânica a ter fundamento na própria Constituição, mas este fundamento está intimamente ligado à função social do direito, positivando uma propriedade funcionalizada a serviço do titular e a serviço da comunidade, mudando do status infra-constitucional para o constitucional.

No entanto, esta mudança de status implicou no reconhecimento de que a noção clássica de propriedade considerada como o direito subjetivo mais completo, espinha dorsal do direito privado, o cerne do direito das coisas ${ }^{52}$ ao qual eram atribuídos todos os benefícios e vantagens do objeto do direito não atendia mais as necessidades coletivas.

Daí o reconhecimento de que o proprietário se sujeita à um feixe de obrigações, oriundas do respeito aos interesses sociais com relevo para a comunidade, implicando no reconhecimento de que o direito de propriedade é relação jurídica complexa onde várias relações se entrelaçam, criando uma pluralidade de direitos e deveres entre às partes..$^{53}$

Isto resulta uma insuficiência na técnica proprietária clássica, considerando a existência de um momento coletivo, nos quais não se pode justificar a propriedade através da lógica

\footnotetext{
${ }^{49}$ Apud RUGGIERO, Roberto de. Instituições do Direito Civil. Vol. 2. Sâo Paulo: Saraiva,1972, p. 300

50 Dentre eles Jhering, Gierke, Marx, Weber e Leon Duguit. SOLON, Ari Marcelo. A função do conceito de direito subjetivo de propriedade. Dissertação de Mestrado apresentado na USP. São Paulo, 1987, p. 27 a 46.

${ }^{51}$ BONAVIDES, Paulo. Do Estado Liberal ao Estado Social. São Paulo: Malheiros, 2007. p. 57-63.

52 RODRIGUES, Silvio. Direito Civil. Direito das Coisas. 28a ed: Edit. Saraiva, vol. 5, 2003, p.76-77.

${ }^{53}$ AMARAL, Francisco. Direito Civil. Introdução. Rio de Janeiro: Forense, 1991, p. 164-165.
} 
dominical como demandas relativas ao meio ambiente, da saúde, do controle sobre os investimentos industriais. ${ }^{54}$

Isto não importa considerar que o direito de propriedade não estava sujeito ao atendimento às finalidades estatais, porém, que não atende na atualidade a idéia de função social do passado, caracterizada pela apropriação em si, como forma máxima de expressão e de desenvolvimento da liberdade humana, dogmática vigente na codificação oitocentista. ${ }^{55}$

Surge uma tendência universal a funcionalização do direito de propriedade ${ }^{56}$ que importa na necessidade de revisitação do conceito de propriedade em razão desta reação social que tornou se jurídica, realçando a função social do direito, já que todo direito tem uma função social já que regula o homem enquanto ser social em suas relações interpessoais.

\section{FUNDAMENTOS DA FUNÇÃO SOCIAL DOS BENS}

Embora a função social tenha sido no âmbito da regulação jurídica da propriedade reconhecida no final do século XIX com o desenvolvimento teórico e a ascensão no século XX do Estado de bem-estar social e a sua previsão nas Constituições sociais ela encontra precedentes filosóficos, também, na antiguidade e na idade média.

Em Aristóteles, já se preocupava com a propriedade e seu uso - distinguindo em propriedade privada e uso comum, propriedade comum e uso privado, propriedade e uso comuns $^{57}$ - sem que cogitasse da propriedade privada e de uso privado, pois para ele a sua justificação era ligada à política, ou seja, era requisito para a vida virtuosa do cidadão.

Assim, três são os argumentos desenvolvidos por Aristóteles na Política para justificar a propriedade: em I.4-10, ele defende a propriedade na perspectiva da casa; depois, e, II.5, é discutido o sistema de propriedade que melhor convém à cidade; e, por fim, em VII.9-10, é estabelecida uma conexão entre propriedade e cidadania.

Na perspectiva da casa, apresenta uma justificação instrumental da propriedade: aquele que está à frente do governo da casa necessita da propriedade para desempenhar a sua função,

\footnotetext{
54 RODOTÀ, Stefano. El terrible derecho: estúdios sobre la propriedad privada. Madrid: Editorial Civitas, 1986. p. 41 e 68.

55 TEPEDINO, Gustavo. A Nova Propriedade. RF, no 306, 1989, p. 74.

56 TRABUCCHI, Alberto. Istituzioni di Diritto Civile. Padova: Casa Editrice Dott Antonio Milani, 1978, p.410

${ }^{57}$ ARISTÓTELES. A Política. op. cit., p. 19-31.
} 
a qual consiste em prover ao sustento desta. A propriedade é uma propriedade do senhor da casa, para realizar as funções desta e não sua como indivíduo ${ }^{58}$.

No contexto da casa, mas no âmbito da cidade intenta responder à seguinte pergunta: deve a propriedade ser tida em comum pelos cidadãos ou em privado? Sustenta que a propriedade comum gera discussões sobre a distribuição e a negligência quanto ao cuidado, enquanto a privada estimula os prazeres, a amizade e virtudes como a moderação ${ }^{59}$.

Porém, a propriedade deve ser de um modo geral, privada, mas comum quanto ao seu uso de forma que o uso comum a pressupõe. A partilha não obrigatória do uso dos bens, assente no exercício da virtude da generosidade dos ricos aos mais pobres, não como uma exigência do Estado, mas como uma consequência dos bons costumes e da eudaimonia.

Uma vez que a propriedade se justifica no âmbito da política, que tem como finalidade a vida justa e feliz, isto é, a vida propriamente humana digna de seres livres, então é inseparável da ética. É inconcebível para ele a ética fora da comunidade política, pois nela a natureza ou essência humana encontra sua realização mais alta.

Assim em Ética a Nicômaco ele aponta que se o fim da política é o bem propriamente humano mesmo se não houver identidade entre o bem do indivíduo e o da Cidade, é manifestamente uma tarefa muito mais importante e mais perfeita conhecer e salvaguardar o bem da Cidade ${ }^{60}$. Subordina, portanto, o bem do indivíduo ao da polis.

Deste modo, não há virtude sem propriedade, mas, ao mesmo tempo, não há propriedade sem virtude ${ }^{61}$ e coloca limites à propriedade privada, submetendo-a ao interesse comum. Aliás, toda a ética aristotélica constitui a defesa da primazia da bem comum face aos interesses particulares.

Em conclusão, para Aristóteles a propriedade encontra-se subordinada à política, é condição necessária de existência da polis e, precisamente por esta razão, a cidade não pode violar as vidas privadas dos cidadãos e deve respeitar a sua propriedade, sob pena de subverter as bases de sua própria existência ${ }^{62}$.

Resgatando o pensamento grego, na Idade Média, Tomás de Aquino considera também que a natureza humana age em direção a um fim, que não é a realização do homem na polis, a

\footnotetext{
58 BRITO, Miguel Nogueira de. A justificação da propriedade privada numa democracia constitucional. Coimbra: Almedina, 2007, p. 69-71.

${ }^{59}$ BRITO, Miguel Nogueira de. op. cit., p. 73.

${ }^{60}$ ARISTÓTELES. Ética a Nicômaco. op. cit., p. 17.

${ }^{61}$ BRITO, Miguel Nogueira de. op. cit.,p. 88.

62 BRITO, Miguel Nogueira de. op. cit.,p. 91.
} 
eudaimonia, mas para um destino superior e transcendente: o novo céu e a nova terra. A civitas é um meio, não um fim. ${ }^{63}$

Há o reconhecimento de uma superioridade do corpo social sobre o indivíduo, do bem comum sobre o bem particular, mas na medida em que essa supremacia do coletivo proporciona às partes condições de, em conjunto, perfazendo o próprio todo, alcançar esse fim do modo mais perfeito. ${ }^{64}$

A discussão da propriedade em Tomás de Aquino se dá nos quadros da lei natural como o conjunto de leis racionais que expressam a ordem das tendências ou inclinações naturais aos fins próprios do homem enquanto pessoa. É natural, pois não procede de fatores culturais, mas da estrutura psicológico-moral do ser humano. Por isso, é universal e imutável.

A lei natural expressa, portanto, as exigências objetivas da natureza humana, necessidades de bem e de justiça. A partir desses preceitos gerais são produzidas conclusões para dispor mais particularmente das coisas. Uma das funções específicas da lei natural é de ser a base da ordem jurídica e da ordem política, que deve ser ordenada ao bem comum.

Ao discutir a propriedade, Tomás de Aquino começa por indagar, na questão 66 da Secunda secundae da Suma Teológica, "se é natural ao homem possuir coisas externas" 65 já que o domínio principal sobre todas as coisas pertence a Deus que, em sua providência, destinou ao homem o natural domínio deles para utilizá-los para a sua utilidade. ${ }^{66}$

O homem tem uma natural soberania das coisas externas no que diz respeito a fazer a utilização das mesmas, que se destinam ao sustento do corpo do homem ${ }^{67}$. Assim, tem, o poder de gerir e dispor dos bens. Tem o homem o poder de adquirir bens e distribuí-los e, assim, é lícito este possuir alguma coisa como própria.

Portanto, Aquino, seguindo Aristóteles, assegura, consoante a prudência, a legalidade e a necessidade da propriedade privada no âmbito da atual condição humana em termos de maior benefício para o bem comum e, ainda, na orientação dos bens para a ordem, eficiência, segurança e paz, não desconectada dos valores instrumentais da moderna liberdade.

Quanto ao uso dos bens pelo homem reduz significativamente a extensão e o alcance do regime da propriedade privada da propriedade: "sob esse aspecto, o homem não deve ter as

\footnotetext{
${ }^{63}$ AQUINO, TOMÁS DE. Suma Teológica. I. II. v. 4. São Paulo: Edições Loyola, 2005, q. 90, a.2

${ }^{64}$ AQUINO, TOMÁS DE. Suma Teológica. I. II. v. 4. São Paulo: Edições Loyola, 2005, q. 50, 4.

${ }^{65}$ AQUINO, TOMÁS DE. Suma Teológica. II. II. v. 6. São Paulo: Edições Loyola, 2005, q. 66, 1.

${ }^{66}$ AQUINO, TOMÁS DE. Suma Teológica. II. II. v. 6. op. cit. p. 156.

${ }^{67}$ AQUINO, TOMÁS DE. Suma Teológica. II. II. v. 6. op. cit. p. 156.
} 
coisas exteriores como próprias, mas como comuns, neste sentido que, de bom grado, cada um as partilhe com os necessitados"68.

O tratamento da propriedade dos bens não é completo sem a direção externa e inclinação pela qual o direito de uso da propriedade está necessariamente obrigado - sua teleologia. Deste modo, a principal exigência da justiça, a de dar a cada um o que é seu, significa algo bem além de um libertário atomismo que ignora o bem comum.

Assim, na filosofia medieval de Aquino acrescenta ao dictum da filosofia clássica de Aristóteles, que é melhor ter a propriedade privada, mas fazer o uso dela comum. Os princípios da filantropia e assistência de bem-estar humanitária surgem para Aquino não como uma teoria de governo, mas sim como uma característica da propriedade privada ${ }^{69}$.

A legitimidade da propriedade se funda a partir da distinção entre o "poder" (potestas) de gerir as coisas e delas dispor e o dever moral de utilizá-las (usus) em proveito de todos. Ao estabelecer que é permitido e mesmo necessário que o homem possua as próprias coisas, Tomás faz da propriedade um verdadeiro direito.

O "uso" (usus) exprime a finalidade a perseguir e como realizar o exercício desse poder. É porque possui o verdadeiro poder e o verdadeiro direito de possuí-los que o homem deve utilizar os bens como "sendo comuns". "Poder" e "uso" formam uma espécie de dupla instância do mesmo direito-dever do qual o homem está investido, no plano ético e jurídico ${ }^{70}$.

\footnotetext{
${ }^{68} \mathrm{AQU} I N O$, TOMÁS DE. Suma Teológica. II. II. v. 6. op. cit. p. 158.

${ }^{69}$ Como bem se expressa, com fundamento no Aquinate, Leão XIII em 1891 em sua Encíclica Rerum Novarum: "E não se apele para a providência do Estado, porque o Estado é posterior ao homem, e antes que ele pudesse formar-se, já o homem tinha recebido da natureza o direito de viver e proteger a sua existência. Não se oponha também à legitimidade da propriedade particular o facto de que Deus concedeu a terra a todo o género humano para a gozar, porque Deus não a concedeu aos homens para que a dominassem confusamente todos juntos. Tal não é o sentido dessa verdade. Ela significa, unicamente, que Deus não assinou uma parte a nenhum homem em particular, mas quis deixar a limitação das propriedades à indústria humana e às instituições dos povos. Aliás, posto que dividida em propriedades particulares, a terra não deixa de servir à utilidade comum de todos, atendendo a que não há ninguém entre os mortais que não se alimente do produto dos campos. Quem os não tem, supre-os pelo trabalho, de maneira que se pode afirmar, com toda a verdade, que o trabalho é o meio universal de prover às necessidades da vida, quer ele se exerça num terreno próprio, quer em alguma parte lucrativa cuja remuneração, sai apenas dos produtos múltiplos da terra, com os quais ela se comuta. De tudo isto resulta, mais uma vez, que a propriedade particular é plenamente conforme à natureza. A terra, sem dúvida, fornece ao homem com abundância as coisas necessárias para a conservação da sua vida e ainda para o seu aperfeiçoamento, mas não poderia fornecê-las sem a cultura e sem os cuidados do homem. Ora, que faz o homem, consumindo os recursos do seu espírito e as forças do seu corpo em procurar esses bens da natureza? Aplica, para assim dizer, a si mesmo a porção da natureza corpórea que cultiva e deixa nela como que um certo cunho da sua pessoa, a ponto que, com toda a justiça, esse bem será possuído de futuro como seu, e não será lícito a ninguém violar o seu direito de qualquer forma que seja".

${ }^{70} A Q U I N O$, TOMÁS DE. Suma Teológica. II. II. v. 6. op. cit. p. 158, nota d.
} 
Nessa explicação compatibilística da propriedade, o interesse privado individual do proprietário e o maior interesse público da sociedade ocupam uma harmônica coexistência teórica. A summa divisio entre privado versus público aparece como uma falsa dicotomia fora da orientação da virtude que assegura a prevenção do colapso em um atomístico egoísmo.

Os bens que alguns têm em superabundância são devidos assim, por direito natural, para o sustento daqueles que não têm, a saber, os bens que o homem tem são legítimos desde que tenham a finalidade de lhe garantir o um espaço vital digno e suficiente para a vida pessoal e social. Se os bens, por direito natural, pertencem a todos, cada indivíduo tem direito à sua parte, sem o que não se cumpriria a destinação universal ${ }^{71}$.

Nesse contexto, o princípio da propriedade privada enquanto princípio moral reclama a sua articulação com outro princípio moral, o dever dos membros da comunidade política concorrerem individualmente para o uso comum das $\operatorname{coisas}^{72}$, o que justificará a privação da coisa em benefício do outro.

Ao tratar do tema, na questão 32 da Secunda secundae do dever de privação em benefício de outrem esclarece que é dever de justiça pôr os bens supérfluos em comum com aqueles que se encontrem em extrema necessidade, bem como, suportar que quaisquer bens próprios sejam usados por alguém em situação de extrema necessidade ${ }^{73}$.

Assim, o fundamento da função social da propriedade não é uma construção moderna da literatura contemporânea e das constituições do século passado, mas antes tem seus precedentes na filosofia da idade antiga e média, que já sujeitavam a legitimidade da apropriação e do uso dos bens ao atendimento das finalidades da coletividade.

\section{AS FUNÇÕES SOCIAIS DA PROPRIEDADE}

Para conceituar a propriedade contemporânea deve-se ter como meta um conceito aberto, atemporal, necessariamente axiológico, que se densifica, adquirindo concretização, ${ }^{74}$ uma vez que a função social que lhe é inerente não tem natureza de princípio programático e nem de limite exterior ao direito, mas integra sua estrutura. ${ }^{75}$

\footnotetext{
${ }^{71}$ MIGOT, Aldo Francisco. A propriedade: natureza e conflito em Tomás de Aquino. Caxias do Sul: EDUCS, 2003, p. 89

72 BRITO, Miguel Nogueira de. op. cit.,p. 173.

73 BRITO, Miguel Nogueira de. op. cit.,p. 176/177.

${ }^{74}$ ARONNE, Ricardo. Propriedade e Domínio. Reexame Sistemático das Noções Nucleares de Direitos Reais. Rio de Janeiro: Renovar, 1999. p.152.

${ }^{75}$ Pode-se afirmar, com uma boa margem de segurança, que a doutrina é quase unânime em reconhecer que a função social não é limite ao direito de propriedade, mas faz parte de seu conteúdo, fundindo-se
} 
A propriedade, se já não é, está em via de ser, instrumento de realização de uma complexa e poliédrica função social e que o impulso a tal radical transformação de sua estrutura e de sua natureza, opera já de acordo com o ordenamento jurídico e com força jurídica apta para atuação. $^{76}$

Assim, deve se reconhecer a função social como integrante da própria estrutura do direito de propriedade, de forma que dela resultam deveres e obrigações ao titular do bem, que é objeto da relação jurídica e, portanto, não correspondem a limites de direito público ou qualquer outra forma de restrição externa. ${ }^{77}$

Por efeito, a noção de propriedade passa a ser redesenhada no sistema jurídico e tem redefinido os seus parâmetros" ${ }^{\prime 78}$, de forma a reconhecer que a propriedade será a relação jurídica complexa que tem por conteúdo as faculdades de uso, gozo e disposição da coisa subordinadas à função social e os deveres, ônus e obrigações em relação a terceiros. ${ }^{79}$

A noção de finalidade de um bem significa assim um poder, mais especificamente, o poder de dar ao objeto da propriedade destino determinado, de vinculá-lo a certo objetivo conforme dispõe a ordem jurídica. Por efeito, a função social se liga antes ao bem do que o direito de propriedade em si.

A função social da propriedade se liga a utilização dos bens, e não à sua titularidade jurídica. Isto significa que independe de quem detenha o título jurídico de proprietário. Os bens, no seu sentido mais amplo, as propriedades, genericamente consideradas, é que estão submetidas a uma destinação social, e não o direito de propriedade em si mesmo ${ }^{80}$.

Assim, a função social da propriedade se realiza mediante atos concretos, de parte de quem efetivamente tem a disponibilidade física dos bens, ou seja, do possuidor, seja ele titular

\footnotetext{
"com o próprio núcleo do conceito de propriedade." (BASTOS, Celso R. A função social como limite constitucional ao D. de Propriedade. Revista de Dir. Constitucional e Ciência Política. no. 6, vol. 4, 1988, p. 25). O princípio da função social da propriedade "se erige numa das vigas mestras de nossa ordem econômica e social" (BASTOS, Celso R. e MARTINS, Ives Gandra. Comentários à Constituição do Brasil. São Paulo: Saraiva Ed., 1989, p.122) e, outros, já afirmam que é mais provável ser a propriedade uma função social, do que ter a propriedade uma função social (BEZERRA, Raimundo Falcão. A função social da propriedade. São Paulo: RDA, vol. 55-56, p. 311, destaque no original) , que já nasceria com ela. Quanto a este ponto e outros aspectos relativos à função social da propriedade, consulte nosso estudo: "A propriedade e a posse: um confronto em torno da Função Social”, Lúmen Júris Editora, 2007.

76 PUGLIATTI, Salvatore. La Proprietá Nel Nuovo Diritto, Milano, Dott. A. Giuffrè Editore, 1964, p $278 .$.

77 RODOTÀ, Stefano. Op. cit p. 221.

${ }^{78}$ ARONNE, Ricardo. Op. cit. p. 173.

${ }^{79}$ LOUREIRO, Francisco E. Op. cit. p. 52.

80 ZAVASCKI, Teori Albino. A tutela da posse na Constituição e no projeto do novo Código Civil. In: A reconstrução do Direito Privado. Org. Judith Martins-Costa. São Paulo : Revista dos Tribunais, 2002, p. 844.
} 
do direito de propriedade ou não, seja ele detentor ou não de título jurídico a justificar sua posse ${ }^{81}$.

Portanto o direito de propriedade não é um absoluto formal, mas só se justifica se a ele é dado um uso social e na medida dessa justificação, mormente naquela classe de bens que não se destina primordialmente ao mercado, como é o caso da terra. O cumprimento da função social é necessário para proteção da propriedade e posse da coisa ${ }^{82}$.

A função social da propriedade impõe o exercício dos bens a interesses extraproprietários, como interesses sociais e ambientais. Isto porque, os bens embora tenham titularidades específicas (públicas ou particulares), por exemplo, em seu aspecto ambiental são de utilização comum de todos $^{83}$, o que se coaduna com sua natureza de direito difuso ${ }^{84}$.

Torna-se necessário para definir o objeto de tutela da função social, distinguir coisa e bem. A coisa é uma individualização factual dos objetos da realidade, constituindo-se o elemento material do conceito jurídico de bem. O bem é a coisa em sua consideração pelo ordenamento jurídico, ou seja, é o bem da vida que, objeto de um interesse humano.

O bem é submetido a uma tutela do direito que conforma uma situação jurídica. Dessa maneira, o direito só leva em conta as coisas após serem objeto de uma apropriação, isto é, de

81 ZAVASCKI, Teori Albino. A tutela da posse na Constituição e no projeto do novo Código Civil. In: A reconstrução do Direito Privado. Org. Judith Martins-Costa. São Paulo : Revista dos Tribunais, 2002, p. 844. 82 O próprio Código Civil de 2002 estabelece que o proprietário não tem o direito de não usar o bem. Isso se infere do art. 1.276, § 2ํ, do Código Civil, que diz que o imóvel que o proprietário abandonar, com a intenção de não mais o conservar em seu patrimônio, e que se não encontrar na posse de outrem, poderá ser arrecadado, como bem vago, e passar, três anos depois, à propriedade do Município ou à do Distrito Federal, se se achar nas respectivas circunscrições. Presumir-se-á de modo absoluto a intenção a que se refere este artigo, quando, cessados os atos de posse, deixar o proprietário de satisfazer os ônus fiscais.

83 "O proprietário do bem socioambiental, ou seja, daquele bem essencial para a manutenção da vida de todas as espécies e de todas as culturas, fica sujeito aos comportamentos apontados. Há um direito à preservação do bem, que é superior ao direito individual de propriedade. É o que chamamos de direito socioambiental de titularidade difusa. A proteção volta-se para o bem, pouco importando a sua titularidade no caso concreto. Por isso, o bem público está sujeito às mesmas regras do bem privado e os direitos socioambientais são exercidos sobre bens alheios.

O bem socioambiental comporta dupla titularidade, a do próprio bem considerado materialmente e a sua representatividade em relação aos demais, compondo o chamado meio ecologicamente equilibrado. Teremos um direito de titularidade individual, o direito de propriedade, e o direito difuso para garantia socioambiental. Tais direitos devem conviver em harmonia". LEMOS, Patrícia Faga Iglecias. Meio ambiente e responsabilidade civil do proprietário: análise do nexo causal. São Paulo: Revista dos Tribunais, 2008, p. 82.

${ }^{84}$ São direitos difusos os direitos supra-individuais, que pertencem a um número indeterminado e praticamente indeterminável de pessoas, as quais não têm entre si nenhuma relação definida, encontramse em uma mesma situação ligadas por circunstâncias de fato, muitas vezes acidentalmente. Por isso, dizse que seu objeto é indivisível, sua proteção beneficia a todos os indivíduos da sociedade e sua agressão prejudica a todos. 
adquirirem uma titularidade jurídica. Antes disso, a coisa é considerada como coisa sem dono res nullius - que não pertence a ninguém.

Por efeito, a função - o poder à conta de um dever, para satisfazer o interesse de outrem, isto é, o conjunto de atos finalisticamente orientados um interesse alheio ou geral ${ }^{85}$ - será exercido pelos bens jurídicos - as coisas qualificadas como jurídicas ao qual são atribuídas titularidades.

No ordenamento brasileiro a chamada função social dos bens, é de fato o atendimento aos interesses previstos em lei, a saber, a adequação às finalidades, ambientais, econômicas e sociais que integram o próprio conteúdo do direito da propriedade e vinculam os seus proprietários.

A função ambiental importa no uso da propriedade deve ser garantida a proteção dos bens ambientais - fana e flora, o patrimônio genético - e os processos ecológicos de forma a garantir o direito difuso ao meio ambiente ecologicamente equilibrado de forma intergeracional ${ }^{86}$.

Assim, a proteção ambiental passa a integrar o próprio conteúdo do direito de propriedade, de modo que no desenvolvimento de atividades privadas deverá, além de atender às necessidades particulares do proprietário, coadunar-se aos interesses da sociedade e harmonizar-se com a preservação dos recursos ambientais nela existentes ${ }^{87}$.

Os institutos ao qual se submete a propriedade privada devem ser lidos a partir também dessa função ambiental de forma a utilizar de modo adequado os recursos naturais e garante a preservação do meio ambiente ${ }^{88}$ isto inclui, por exemplo, as áreas de preservação permanente ${ }^{89}$ necessárias para a preservação da biodiversidade, recursos hídricos e outros.

Em outro vértice, a função econômica envolve a utilização da propriedade privada para exercício de atividade produtiva de acordo com os fins da ordem econômica - valorização do trabalho humano e livre iniciativa assegurando a todos existência digna - com respeito aos seus princípios - defesa do consumidor, redução das desigualdades e outros ${ }^{90}$.

Assim, ao consagrar o direito de propriedade junto com a função social como princípios fundantes da ordem econômica, a ordem econômica determinas certas posições jurídicas ao seu

\footnotetext{
85 MELLO, Celso Antônio Bandeira de. O desvio de poder. Revista de Direito Administrativo. Rio de Janeiro: Renovar, n. 172, abr.-jun., 1988.

${ }^{86}$ BRASIL, Constituição da República Federativa do Brasil de 05 de Outubro de 1988. Art. 225.

87 CAVEDON, Fernanda de Salles. Função social e ambiental da propriedade. Florianópolis: Visualbooks, 2003, p. 67.

88 HUMBERT, Georges Louis Hage. Op. cit. p. 127-128.

${ }^{89}$ BRASIL, Lei no 12.651 de 25 de Maio de 2012. Art. 3ㅇinciso II e 4.

${ }^{90}$ BRASIL, Constituição da República Federativa do Brasil de 05 de Outubro de 1988. Art. 170.
} 
titular quanto ao atendimento de certas exigências no exercício da atividade econômica decorrente do papel de regulador assumido pelo Estado. ${ }^{91}$

Por efeito, na propriedade rural exige-se, por exemplo, o aproveitamento racional e adequado na exploração econômica ${ }^{92}$ sob pena de desapropriação por interesse social, para fins de reforma agrária ${ }^{93}$ garantindo uma propriedade produtiva, que se adéque ao atendimento dos fins estatais econômicos como a política agrícola.

Determina a Constituição Federal, também, além do atendimento às finalidades econômicas e ambientais, o respeito às funções sociais latu sensu da propriedade através de uma cláusula gera ${ }^{94}$, bem como, de deveres fundamentais e regras específicas à propriedade urbana ${ }^{95}$ e rural ${ }^{96}$.

Assim, prevê como deveres fundamentais correlatos à função social como, por exemplo, com as restrições à propriedade privada através da desapropriação ${ }^{97}$ requisição, ${ }^{98}$ tombamento ${ }^{99}$, limitações administrativas ${ }^{100}$ ou com limites à sua proteção como, por exemplo, a sujeição das marcas e patentes aos interesse social e desenvolvimento ${ }^{101}$.

Sujeita a propriedade rural privada ao necessário atendimento ao interesse social de reforma agrária, excluída a pequena propriedade e a propriedade produtiva ${ }^{102}$ e as terras públicas e devolutas ao atendimento ao plano nacional de reforma agrária ${ }^{103}$ sob pena de, por exemplo, desapropriação ${ }^{104}$ ou usucapião ${ }^{105}$.

Por fim, também, determina a sujeição da propriedade urbana às finalidades previstas no plano diretor enquanto instrumento de ordenação do pleno desenvolvimento da cidade e garantia do bem- estar de seus habitantes ${ }^{106}$. Para tanto designa essas finalidades como funções sociais da cidade.

\footnotetext{
${ }^{91}$ FRANCO, Paulo Fernando; PORTO, Antônio José Maristrello. Uma Análise Também Econômica do Direito de Propriedade. Economic Analysis of Law Review, V. 7, no 1, p. 207 - 232, Jan-Jun, 2016. p.

92 BRASIL, Constituição da República Federativa do Brasil de 05 de Outubro de 1988. Art. 186 inciso I.

93 BRASIL, Constituição da República Federativa do Brasil de 05 de Outubro de 1988. Art. 184.

94 BRASIL, Constituição da República Federativa do Brasil de 05 de Outubro de 1988. Art. 5 XXIII

95 BRASIL, Constituição da República Federativa do Brasil, de 05 de Outubro de 1988. Art. 182 §4은

${ }^{96}$ BRASIL, Constituição da República Federativa do Brasil, de 05 de Outubro de 1988. Art. 184.

97 BRASIL, Constituição da República Federativa do Brasil, de 05 de Outubro de 1988. Art. 5o XXIV.

98 BRASIL, Constituição da República Federativa do Brasil, de 05 de Outubro de 1988. Art. 5 XXV.

99 BRASIL, Constituição da República Federativa do Brasil, de 05 de Outubro de 1988. Art. 216 §único.

100 BRASIL, Constituição da República Federativa do Brasil, de 05 de Outubro de 1988. Art. $182 \S \S$

101 BRASIL, Constituição da República Federativa do Brasil, de 05 de Outubro de 1988. Art. 5 XXIX.

102 BRASIL, Constituição da República Federativa do Brasil, de 05 de Outubro de 1988. Art. 184 c/c 185.

103 BRASIL, Constituição da República Federativa do Brasil, de 05 de Outubro de 1988. Art. 188.

104 BRASIL, Constituição da República Federativa do Brasil, de 05 de Outubro de 1988. Art. 184.

105 BRASIL, Constituição da República Federativa do Brasil, de 05 de Outubro de 1988. Art. 191.

106 BRASIL, Constituição da República Federativa do Brasil, de 05 de Outubro de 1988. Art. 182.
} 


\section{PROPRIEDADE E FUNÇÕES SOCIAIS DA CIDADE}

A regulação normativa da propriedade urbana exorbita do sistema geral civil para constituir um regime próprio onde se supera a sua concepção estática de fonte de acumulação de capital para uma visão dinâmica enquanto objeto de planejamento político no interesse geral visando o desenvolvimento das funções sociais ${ }^{107}$.

Isto não afasta os interesses privados do titular do direito de propriedade, mas condiciona o bem ao atendimento dos princípios fundantes deste sistema, bem como, o regime constitucional e legal do respectivo instituto ${ }^{108}$, ou seja, impõe a sujeição da propriedade urbana as funções sociais da cidade.

Isto porque as funções sociais da cidade correspondem na realidade interesses difusos uma vez que não é possível identificar quais sujeitos - proprietários, moradores, trabalhadores, migrantes - são afetados pelas atividades desenvolvidas na mesma, embora todos por estarem na urbe tenham o direito ao bem-estar. ${ }^{109}$

A identificação de quais sejam tais interesses que a ordem jurídica consagrou como um feixe dessa função social exercida pelo titular da propriedade na cidade, porém, é controverso já que a norma constitucional veicula apenas a expressão ${ }^{110}$ e, portanto, tem natureza principiológica com alto grau de generalidade e de abstração ${ }^{111}$.

A rigor poderia considerar como funções sociais da cidade a própria realização dos direitos sociais - a educação, a saúde, a alimentação, o trabalho, a moradia, o transporte, o lazer, a segurança, a previdência social, a proteção à maternidade e à infância, a assistência aos desamparados - na cidade ${ }^{112}$.

Porém, há de se admitir que o ente público na regulação da cidade através do plano diretor e o particular como titular do direito de propriedade urbana se sujeitam mais do que

\footnotetext{
107 TORRES, Marcos Alcino. Impacto das Novas Idéias na Dogmática do Direito de Propriedade, Revista de Direito da Cidade, v. 3, n. 2, 2001, p. 115.

108 TORRES, Marcos Alcino. Op. cit. p. 115.

109 SAULE JUNIOR, Nelson. SAULE JUNIOR, Nelson. O direito à moradia como responsabilidade do Estado Brasileiro in: SAULE JUNIOR, Nelson (Org). Direito à Cidade: Trilhas Legais para o Direito Pas Cidades Sustentáveis. Porto Alegre: Sérgio Antônio Fabris, 2002. p. 61.

${ }^{110}$ BRASIL, Constituição da República Federativa do Brasil, de 05 de Outubro de 1988. Art. 182.

111 Sobre o regime constitucional da cidade consulte-se: MOURA, Emerson Affonso da Costa. A Constitucionalização do Direito da Cidade. urbe, Rev. Bras. Gest. Urbana [online]. 2017, vol.9, n.3, pp.527542.

${ }^{112}$ BRASIL, Constituição da República Federativa do Brasil, de 05 de Outubro de 1988. Art. 6.
} 
apenas a concretização dos direitos sociais, porém, a realização dos direitos fundamentais, que tem eficácia imediata para todos sem discriminar na cidade ou na zona rural113.

Tradicionalmente, considerava-se como funções sociais da cidade pela literatura dominante ${ }^{114}$ aquelas previstas na Carta de Atenas de $1933^{115}$ como funções do espaço urbano, ou seja, atividades tipicamente a serem desenvolvidas pelo espaço físico-territorial da urbe, a saber, habitação, trabalho, circulação e recreação.

Porém, com a nova Carta de Atenas de 2003 e a visão de uma cidade futura coerente parece que se ampliam tais funções para abranger outros interesses a serem protegidos como a multiculturalidade, mobilidade, proteção intergeracional, identidade social, o direito de equipamento e serviços urbanos dentre outros. ${ }^{116}$

Se insere dentro de uma proposta de mudança de paradigma onde questiona-se a construção da noção da cidade à partir de uma perspectiva desenvolvimentista e busca a criação de uma cidade sustentável e ligada as demais comunidades com a busca de novas finalidades que permitam uma cidade para todos. ${ }^{117}$

Ademais, há de se considerar que o Estatuto da Cidade ao regular a norma constitucional no que tange aos princípios gerais da política urbana estipulou diversas diretrizes, que orientam o pleno desenvolvimento das funções sociais da cidade e da propriedade urbana ${ }^{118}$.

Parte da literatura não consideram tais diretrizes como as funções em si, mas como o conjunto de situações urbanísticas de fato e de direito que irão assegurar a realização da política urbana, ou seja, os instrumentos que visam concretizar o pleno desenvolvimento das funções sociais da cidade e da propriedade urbana. ${ }^{119}$

De fato, parece inadequado considerar que as funções sociais da cidade se confundam com os instrumentos previstos de política urbana, bem como, que se limitem as finalidades previstas nas Cartas de Atenas, que antes apresentam proposições advindas do Congresso Nacional de Arquitetura Moderna.

\footnotetext{
113 BRASIL, Constituição da República Federativa do Brasil, de 05 de Outubro de 1988. Art. 5 § 1 o

114 MEIRELLES, Hely Lopes. Direito urbanístico. São Paulo: Malheiros, 1993.

115 A carta de atenas foi aprovada pela Assembléia do Congresso Nacional de Arquitetura Moderna em 1933 e aborda a cidade como parte de um conjunto econômico, social e político. O texto está disponível em: http://portal.iphan.gov.br/uploads/ckfinder/arquivos/Carta\%20de\%20Atenas\%201933.pdf Acesso em 14.01.2019.

116 Disponível em: https://paginas.fe.up.pt/construcao2004/c2004/docs/SAT 02 carta\%20atenas.pdf Acesso em 14.01.2019.

117 KANASHIRO, Milena. Da antiga à nova Carta de Atenas - em busca de um paradigma espacial de sustentabilidade. Desenvolvimento e Meio Ambiente, n. 9, p. 33-37, jan./jun. 2004. Editora UFPR, p. 36.

118 BRASIL, Lei Federal no 10.257 de 10 de Julho de 2001. Art. 2.

${ }^{119}$ CARVALHO FILHO, José dos Santos. Comentários ao Estatuto da Cidade. São Paulo: Atlas, 2013. p. 27.
} 
Deve-se fixar uma delimitação jurídica para as funções sociais da cidade que seja adequada não apenas a função social que a propriedade privada deve assumir no âmbito urbano, mas igualmente os demais bens e valores do ordenamento jurídico-constitucional a serem perseguidos no campos da urbe.

Para alguns poderiam se agrupar de forma doutrinária grupos de funções sociais da cidade convencionando funções sociais - habitação, trabalho, lazer e mobilidade - de cidadania - educação, saúde, segurança e proteção - e de gestão - prestação de serviços, planejamento, preservação do patrimônio cultural e natural, e sustentabilidade urbana ${ }^{120}$.

Neste viés, parece adequado considerar que as funções sociais da cidade irão abranger de fato a implementação de ações e programas estatais e a observância pela propriedade privada de um sistema formado por interesses coletivos e individuais a serem perseguidos no âmbito da cidade. ${ }^{121}$

Inegável, que isto abrangerá, funções ligadas à realização de interesses sociais - como os direitos à saúde, educação, assistência - até finalidades que envolvem interesses individuais como a segurança e a vida - inclusive econômicos - como a liberdade de exercer atividade econômica e outros.

Uma vez que as funções sociais da cidade são voltadas para atender os interesses do grupo social urbano de forma a garantir condições dignas de vida, essa pluralidade de funções por vezes guarda intensa litigiosidade e pode gerar variados complexos conflitos urbanos que surgem quando uma for antagonizada por outro. ${ }^{122}$

Assim, por exemplo, tem-se a proteção do meio ambiente ecologicamente equilibrado e a moradia, de forma que as ocupações de áreas de preservação permanente podem gerar conflitos entre funções sociais igualmente protegidas na cidade, que devem ser compatibilizadas.

É inevitável que tais funções sociais da cidades não guardam entre si qualquer tipo de hierarquia, mas antes representam igualmente objetivos e valores a serem igualmente perseguidos e realizados de forma concomitante, o que resultará como ocorre com os demais princípios constitucionais a necessidade de ponderação no caso concreto.

Tal compreensão coaduna com uma ordem jurídico-constitucional pluralista, bem como, com a prospecção da cidade e da sua ordenação jurídica onde deve se proteger uma série de

\footnotetext{
120 GARCIAS, Carlos Mello; BERNARDI, Jorge Luiz. As Funções Sociais da Cidade. Revista de Direitos Fundamentais e Democracia. V. 4., 2008. p. 9.

${ }^{121}$ CARVALHO FILHO, José dos Santos. Comentário... Op. cit. p. 29.

122 SAULE JUNIOR, Nelson. Op. cit. p. 61.
} 
interesses coletivos e individuais adequando a propriedade de bens à função social, aqui delimitada em um feixe de funções sociais da cidade.

\section{CONCLUSÃO}

De todo exposto no trabalho verifica-se que o reconhecimento da função social da propriedade não se limita exclusivamente na previsão nos deveres fundamentais previstos na Constituição Federal de adequação dos bens privados a determinados interesses sociais através dos instrumentos tradicionais como a desapropriação ou a requisição.

É possível reconhecer inúmeros interesses coletivos e individuais que irão abranger a noção de função social da propriedade, inclusive, aqueles que a Constituição Federal submeteu a propriedade privada à política urbana para fim de atendimento às funções sociais da cidades e o bem-estar dos seus habitantes.

Com as funções sociais da cidade densificam-se interesses coletivos e individuais que deverá o titular da propriedade situada em área urbana compatibilizar no exercício da sua autonomia privada de forma a garantir que sejam atendidas as finalidades previstas na política urbana no que tange ao desenvolvimento e expansão da cidade.

\section{REFERÊNCIAS}

ALMEIDA, Francisco de P. Lacerda de. Direito das cousas. Rio de janeiro: Ribeiro dos Santos, 1908

AMARAL, Francisco. Direito Civil. Introdução. Rio de Janeiro: Forense, 1991

AQUINO, TOMÁS DE. Suma Teológica. I. II. v. 4. São Paulo: Edições Loyola, 2005

ARONNE, Ricardo. Propriedade e Domínio. Reexame Sistemático das Noções Nucleares de Direitos Reais. Rio de Janeiro: Renovar, 1999.

ARRUDA ALVIM. Breves Anotações para uma Teoria Geral dos Direitos Reais, in Posse e Propriedade. São Paulo: Saraiva Ed., 1987

ALVES, José Carlos M.. Direito Romano. 9ạ edição. vol I. Rio de Janeiro: Forense, 1995 
ARISTÓTELES. A Política. Trad. Nestor Silveira Chaves. 6aed. São Paulo: Atena Editora, 1960

BASTOS, Celso R. e MARTINS, Ives Gandra. Comentários à Constituição do Brasil. São Paulo: Saraiva Ed., 1989

BESSONE, Darcy. Direitos Reais. Rio de Janeiro: Saraiva, 1988

BEZERRA, Raimundo Falcão. A função social da propriedade. São Paulo: RDA, vol. 55-56,

BOBBIO, Norberto. Direito e Estado no Pensamento de E. Kant. 2a. ed. Edurb, 1992.

BONAVIDES, Paulo. Do Estado Liberal ao Estado Social. São Paulo: Malheiros, 2007.

BRITO, Miguel Nogueira de. A justificação da propriedade privada numa democracia constitucional. Coimbra: Almedina, 2007

BURNS, Edward Mcnall. História da Civilização Ocidental. 1ำ vol. Trad. Alexandre Costa. Ed. Globo S-A, 1980

KANASHIRO, Milena. Da antiga à nova Carta de Atenas - em busca de um paradigma espacial de sustentabilidade. Desenvolvimento e Meio Ambiente, n. 9, p. 33-37, jan./jun. 2004. Editora UFPR

CAVEDON, Fernanda de Salles. Função social e ambiental da propriedade. Florianópolis: Visualbooks, 2003

COMPARATO, Fábio Konder. A Afirmação Histórica dos Direitos Humanos. São Paulo, Ed. Saraiva, 1999.

CRETELLA JUNIOR, José Curso de Direito Romano. 11a edição. Rio de Janeiro: Forense, 1987

FRANCO, Paulo Fernando; PORTO, Antônio José Maristrello. Uma Análise Também Econômica do Direito de Propriedade. Economic Analysis of Law Review, V. 7, no 1, p. 207 - 232 
FISCHBACH, Oskar Georg. Teoria General del Estado. Trad. Rafael L. Tapia. 4a ed. Barcelona: Editorial Labor S-A., 1949

FULGÊNGIO, Tito. Direito de vizinhança. Rio de Janeiro: Forense, 1959

GARCIAS, Carlos Mello; BERNARDI, Jorge Luiz. As Funções Sociais da Cidade. Revista de Direitos Fundamentais e Democracia. V. 4., 2008.

GASSEN, Valcir. A Natureza Histórica da Instituição do Direito de Propriedade. In Fundamentos de História do Direito, Org. Antonio Carlos Wolkmer, 2ª ed. Belo Horizonte: Del Rey, 2006.

GILISSEN, John. Introdução Histórica ao Direito.3 ed. Lisboa: Fundação Calouste, 1995.

GONÇALVES, Luiz da Cunha. Tratado de Direito Civil em Comentário ao Código Civil Portugues. 2ạ edição. vol. XI. Tomo I, anotado por Jayme Landin. São Paulo: Max Limonad. 1968.

IHERING, Rudolf von. A Finalidade do Direito. Tomo I. Trad. Heder K. Hoffmann, 1a ed. São Paulo: Bookseller Editora e Distribuidora, 2003

KANASHIRO, Milena. Da antiga à nova Carta de Atenas - em busca de um paradigma espacial de sustentabilidade. Desenvolvimento e Meio Ambiente, n. 9, p. 33-37, jan./jun. 2004. Editora UFPR

KELSEN, Hans. Teoria Pura do Direito. Trad. João Batista Machado. São Paulo: Ed. Martins Fontes, 1985

KICH, Bruno C. A Propriedade na Ordem Jurídica, Econômica e Ideológica. Porto Alegre: Sérgio Fabris, 2004

LEMOS, Patrícia Faga Iglecias. Meio ambiente e responsabilidade civil do proprietário: análise do nexo causal. São Paulo: Revista dos Tribunais, 2008 
MELLO, Celso Antônio Bandeira de. O desvio de poder. Revista de Direito Administrativo. Rio de Janeiro: Renovar, n. 172, abr.-jun., 1988.

MEIRELLES, Hely Lopes. Direito urbanístico. São Paulo: Malheiros, 1993.

MIGOT, Aldo Francisco. A propriedade: natureza e conflito em Tomás de Aquino. Caxias do Sul: EDUCS, 2003,

MONTEIRO, Washington de Barros, Curso de Direito Civil. vol. 3. 37ạ ed. São Paulo: Saraiva, 2003.

MONTEIRO FILHO, Ralpho Waldo de Barro. Função social da propriedade: conteúdo e diretrizes para sua compreensão. Revista Forense. Vol. 397.

MOURA, Emerson Affonso da Costa. A Constitucionalização do Direito da Cidade. urbe, Rev. Bras. Gest. Urbana [online]. 2017, vol.9, n.3.

PAPANO, Jose R., KIPER, Cláudio M., DILLON, Gregório A., CAUSSE, Jorge R. Derechos Reales. Tomo I. Buenos Aires: Ediciones Depalma, 1993

PASUKANIS, Eugeny B.. A Teoria Geral do Direito e o Marxismo. Rio de Janeiro: Renovar, 1989.

PUGLIATTI, Salvatore. La Proprietá Nel Nuovo Diritto, Milano, Dott. A. Giuffrè Editore, 1964

PEREIRA, Lafayette R. Direito das Coisas. Vol I. Brasilia: Senado Federal, 2004

PEREIRA, Virgílio de Sá. Direito das Coisas. vol. VIII. São Paulo: Jacintho Ribeiro dos Santos, 1924

PEZZELLA, Maria Cristina Cereser. Propriedade Privada no Direito Romano. Porto Alegre: Sergio A. Fabris Editor, 1998

RADBRUCH, Gustav. Filosofia do Direito. Trad. L. Cabral de Moncada. 6a ed. Coimbra: Armênio Amado Editor, Sucessor, 1979. 
RODOTÀ, Stefano. El terrible derecho: estúdios sobre la propriedad privada. Madrid: Editorial Civitas, 1986.

RODRIGUES, Silvio. Direito Civil. Direito das Coisas. 28 ed: Edit. Saraiva, vol. 5, 2003

RIZZARDO, Arnaldo. Direito das Coisas. 2aㅡ ed. Rio de Janeiro: Ed. Forense, 2006.

RUGGIERO, Roberto de. Instituições do Direito Civil. Vol. 2. Sâo Paulo: Saraiva,1972.

SOLON, Ari Marcelo. A função do conceito de direito subjetivo de propriedade. Dissertação de Mestrado apresentado na USP. São Paulo, 1987

SOUZA, Marnoco e. História das Instituições do Direito Romano, Penínsular e Portugues. Coimbra: Imprensa de Universidade, 1904.

TEPEDINO, Gustavo. A Nova Propriedade. RF, no 306, 1989

TORRES, Marcos Alcino. Impacto das Novas Idéias na Dogmática do Direito de Propriedade, Revista de Direito da Cidade, v. 3, n. 2, 2001.

TRABUCCHI, Alberto. Istituzioni di Diritto Civile. Padova: Casa Editrice Dott Antonio Milani, 1978

ZAVASCKI, Teori Albino. A tutela da posse na Constituição e no projeto do novo Código Civil. In: A reconstrução do Direito Privado. Org. Judith Martins-Costa. São Paulo: Revista dos Tribunais, 2002.

Trabalho enviado em 26 de junho de 2019

Aceito em 28 de janeiro de 2019 